\title{
Erosive potential of sugar-free hard candies dissolved in water and artificial saliva
}

\author{
Maria Mercês Aquino Gouveia Farias', Magatha Marquetti Lazzaris de Oliveira', Beatriz Helena Eger Schmitt', \\ Eliane Garcia da Silveira', Silvana Marchiori de Araújo ${ }^{1}$
}

${ }^{1}$ Universidade do Vale do Itajaí, School of Dentistry, Area of Pediatric Dentistry, Itajaí, SC, Brazil

\begin{abstract}
Aim: To compare the acidity of sugar-free hard candies dissolved in water and artificial saliva. Methods: Sugar-free Flopi Florestall hard candies (grape, strawberry, cherry, orange, ginger, lemon balm, fennel) were selected and grouped in 2 groups: G-1 (candies dissolved in distilled water) and G-2 (candies dissolved in artificial saliva). Candies were triturated with a porcelain pestle, yielding two samples of $20 \mathrm{~g}$. Samples were dissolved in $120 \mathrm{~mL}$ distilled water (G-1) and $120 \mathrm{~mL}$ artificial saliva ( $20 \mathrm{mM} \mathrm{NaHCO}_{3}, 3 \mathrm{mM} \mathrm{NaH}_{2} \mathrm{PO}_{4} \cdot \mathrm{H}_{2} \mathrm{O}$ and $\left.1 \mathrm{mM} \mathrm{CaCl}_{2} \cdot 2 \mathrm{H}_{2} \mathrm{O}\right)(\mathrm{G}-2)$, obtaining three samples of $30 \mathrm{~mL}$ for each of the flavors and groups. $\mathrm{pH}$ was measured using potentiometer and combined glass electrode. Titratable acidity was evaluated by adding $100 \mu \mathrm{L} 1 \mathrm{M} \mathrm{NaOH}$ aliquots until reaching pH 5.5. For statistical analysis, analysis of variance (ANOVA) was used. Means were compared by the Tukey test at $5 \%$ significance level $(p<0.05)$ Results: All flavors of $\mathrm{G}-1$ showed $\mathrm{pH}$ values below 5.5. Comparison of groups in the same flavor showed a significant increase in $\mathrm{pH}$ in flavors of G-2. Comparison of the titratable acidity between G-1 and G-2, showed that fruit flavors were significantly different from each other, with reduced acidity in G-2. Conclusions: All evaluated candies are acid, and dilution in artificial saliva raised their $\mathrm{pH}$ and lowered their titratable acidity, reducing their erosive potential.
\end{abstract}

Keywords: Tooth Erosion. Candies. Saliva, Artificial. Hydrogen-Ion Concentration. Acidity.

\section{Introduction}

Dental erosion is a multifactorial disorder in which factors such as structural characteristics of dental tissues, physiological properties of saliva, acidic sources from intrinsic and extrinsic origin, as well as behavioral, educational, socio-economic factors should be considered ${ }^{1,2}$. Its prevalence is increasing and its clinical management requires diagnosis and assessment of risk factors in order to understand the various factors associated with its etiology $y^{3}$.

The most important exposure to extrinsic acids comes from diet ${ }^{1}$. Some physicochemical characteristics influence the erosivity of food like the type of acid, $\mathrm{pH}$, titratable acidity, chelating potential, calcium and phosphate concentration, temperature and adhesion ${ }^{4}$. Especially, $\mathrm{pH}$, titratable acidity and calcium content are the most

Received for publication: August 10, 2016 Accepted: August 25, 2016

Correspondence to: Maria Mercês Aquino Gouveia Farias Rua Bartolomeu de Gusmão 209, Carianos CEP: 88047-520 - Florianópolis, SC

E-mail: mercesfarias@gmail.com important features for determining the erosive potential of a product ${ }^{4}$. In addition, several biological factors related to salivary protection mechanisms have an important role in the erosive wear, especially dilution of the erosive agent, salivary cleaning, film formation and buffer capacity, which are able to modulate the erosive wear ${ }^{2}$.

Recently, along with the economic development in many countries, there has been a wide range of industrial acidic products accompanied by intense advertisement, increasing the exposure of children and adolescents to these products at increasingly 
early ages ${ }^{5}$. Acidic candies are among these products and the literature about their erosivity is relatively scarce, compared to studies addressing the erosive potential of industrialized beverages $^{6}$. Recent studies have shown the consumption of acidic sweets as a potential risk factor for dental erosion ${ }^{7,8}$.

Sugar-free products are accepted as safe for teeth for being non- cariogenic. However, the presence of acidic components (citric, phosphoric, ascorbic, malic, tartaric, oxalic, carbonic and fumaric acids) may turn them an acid source, which is a risk factor for dental erosion, making them able to cause damage to the tooth structure ${ }^{9,10}$.

A previous study compared the erosive potential of original-flavor candies and sour candies dissolved in artificial saliva and water. The authors observed that saliva was able to reduce the erosive potential of both flavors, but reduction was more significant for original-flavor candies than on sour candies $^{11}$

Seeking to contribute to the research of the erosive potential of candies available in Brazil, the aim of this study was to measure and compare the erosive potential of sugar-free hard candies dissolved in water and artificial saliva.

\section{Material and methods}

This was a two-factor experiment. Factor A: 2 dilution media: group 1 (G1) - distilled water and group 2 (G2), artificial saliva. Factor B: seven flavors of sugar-free hard candies Flopi Florestal ${ }^{\circledR}$ (Florestal Alimentos S.A.; Lajeado, RS, Brazil) available at supermarkets, all in a single package with opening and closing system as a common feature (Chart 1).

Chart 1 - Selected flavors and product composition according to the manufacturer.

\begin{tabular}{|ll|}
\hline Flavors & Composition \\
\hline $\begin{array}{l}\text { Sugar-free Flopi (Florestal }(\text { ) flavors: } \\
\text { cherry, orange, grape, strawberry, }\end{array}$ & Vitamin C, sweetener sorbitol, arabic gum \\
lemon balm, fennel & thickener, citric acid, flavor, artificial color. \\
\hline
\end{tabular}

\section{Analysis of $\mathrm{pH}$ and titratable acidity}

Two packs of $40 \mathrm{~g}$ of sugar-free Flopi Florestal $\AA$ candies were employed (cherry, strawberry, orange, grape, lemon, fennel and ginger).

Candies from each package were ground by a $305 \mathrm{~mL}$ porcelain pestle (Nalgon Equipamentos Científicos; Itupeva, SP, Brazil). From the resulting powder, two samples of $20 \mathrm{~g}$ were weighed for this purpose, on an analytical and precision electronic scale (AE200S Mettler-Toledo Ind. e Com. Ltda., Barueri, SP, Brazil). The powder samples were dissolved in $120 \mathrm{~mL}$ of distilled water $(\mathrm{pH}=6.2)(\mathrm{G}-1)$ and in $120 \mathrm{~mL}$ artificial saliva $(20 \mathrm{mM}$ $\mathrm{NaHCO}_{3}, 3 \mathrm{mM} \mathrm{NaH}_{2} \mathrm{PO}_{4} \cdot \mathrm{H}_{2} \mathrm{O}$ and $\left.1 \mathrm{mM} \mathrm{CaCl}_{2} \cdot 2 \mathrm{H}_{2} \mathrm{O}\right)(\mathrm{pH}=7.39)$ (G-2) with a glass rod until reaching a homogeneous solution. From these solutions were obtained three samples of $30 \mathrm{~mL}$ for each flavor in each group. This process allowed for reading $\mathrm{pH}$ and titratable acidity in triplicate ${ }^{11}$.
The $\mathrm{pH}$ of all solutions was measured (G-1 and G-2) at room temperature and constant stirring (Magnetic Stirrer; Fisaton Equipamentos Científicos, São Paulo, SP, Brazil), using potentiometer and combined glass electrode (Tec-2; TECNAL Equipamentos para Laboratórios, Piracicaba, SP, Brazil) previously calibrated with $\mathrm{pH} 7.0$ and $\mathrm{pH} 4.0$ standard solutions, before each reading.

Only in solutions with pH values below 5.5 (G-1 and G-2), titratable acidity (buffer capacity) was measured by adding aliquots of $100 \mu \mathrm{L}$ of $1 \mathrm{M} \mathrm{NaOH}$ under constant stirring (Fisaton) to reach $\mathrm{pH}$ 5.5. The results were statistically analyzed by twoway ANOVA, followed by Tukey's multiple-comparison test at $\mathrm{p}<0.05$

\section{Results}

All candies dissolved in water showed $\mathrm{pH}$ values below 5.5. When dissolved in artificial saliva only, fruit flavors maintained their acidity. The ANOVA F-test was significant $(p<0.05)$ in the comparison among the seven flavors and between groups (G1 and G2) (Table 1). Comparing groups for titratable acidity, fruit flavors had significantly lower values when dissolved in artificial saliva $(p<0.05)$ (Table 2). The flavors ginger, lemon and fennel showed low titratable acidity when dissolved in water.

Table 1 - Mean \pm standard deviation values of $\mathrm{pH}$ of the different flavors of candies, after dilution in water $(\mathrm{G} 1)$ or artificial saliva (G2).

\begin{tabular}{lll}
\hline Flavors & G1- Water & G2 -Artificial Saliva \\
Grape & $2.55 \pm 0.02 \mathrm{D} \mathrm{b}$ & $4.42 \pm 0.01 \mathrm{~F} \mathrm{a}$ \\
Strawberry & $2.82 \pm 0.06 \mathrm{C} \mathrm{b}$ & $4.80 \pm 0.01 \mathrm{C} \mathrm{a}$ \\
Cherry & $2.86 \pm 0.06 \mathrm{C} \mathrm{b}$ & $4.54 \pm 0.02 \mathrm{E} \mathrm{a}$ \\
Orange & $3.05 \pm 0.03 \mathrm{~B} \mathrm{~b}$ & $4.67 \pm 0.01 \mathrm{D} \mathrm{a}$ \\
Ginger & $4.33 \pm 0.06 \mathrm{~A} \mathrm{~b}$ & $7.44 \pm 0.02 \mathrm{AB} \mathrm{a}$ \\
Lemon balm & $4.40 \pm 0.05 \mathrm{~A} \mathrm{~b}$ & $7.37 \pm 0.02 \mathrm{~B} \mathrm{a}$ \\
Fennel & $4.44 \pm 0.03 \mathrm{Ab}$ & $7.50 \pm 0.05 \mathrm{~A} \mathrm{a}$ \\
\hline
\end{tabular}

Means followed by the same capital letter in columns and small letter in rows do not differ significantly from each other by the Tukey's test $(p<0.05)$.

Table 2 - Mean \pm standard deviation values of titratable acidity* of the different flavors of candies, after dilution in water $(\mathrm{G} 1)$ or artificial saliva (G2).

\begin{tabular}{lll}
\hline Flavors & G1 - Water & G2 -Artificial Saliva \\
Grape & $733.3 \pm 57.74 \mathrm{~A} \mathrm{a}$ & $266.7 \pm 57.74 \mathrm{~B} \mathrm{~b}$ \\
Strawberry & $566.7 \pm 57.74 \mathrm{~B} \mathrm{a}$ & $200.0 \pm 0.0 \mathrm{~B} \mathrm{~b}$ \\
Cherry & $566.7 \pm 57.74 \mathrm{~B} \mathrm{a}$ & $166.7 \pm 57.74 \mathrm{~B} \mathrm{~b}$ \\
Orange & $600.0 \pm 0.0 \mathrm{~B} \mathrm{a}$ & $200.0 \pm 0.0 \mathrm{~B} \mathrm{~b}$ \\
Ginger & $100 \pm 0.0$ & 0 \\
Lemon balm & $100 \pm 0.0$ & 0 \\
Fennel & $100 \pm 0.0$ & 0 \\
\hline
\end{tabular}

Means followed by the same capital letter in columns and small letter in rows do not differ significantly from each other by the Tukey test $(p<0.05)$. *volume $(\mu \mathrm{L})$ of $1 \mathrm{M}$ $\mathrm{NaOH}$ required to reach $\mathrm{pH} 5.5$. 


\section{Discussion}

In recent years, the production and supply of new types of candies/sweets increased significantly. The relationship between the consumption of candies/sweets and tooth decay is widely reported in literature ${ }^{5}$. However, in addition to their cariogenic potential, many candies contain organic acids (citric, malic, fumaric, ascorbic, acetic, lactic, tartaric acids) in their composition, isolated or combined, in different concentrations ${ }^{5,6}$. The excessive consumption of these products was pointed out as a potential risk factor for dental erosion ${ }^{7,8}$.

The analyzed products had the same components, but their concentrations were not described by manufacturers. Probably the variation in concentration of components is responsible for variations in $\mathrm{pH}$ and titratable acidity, as found in this study.

There are various artificial saliva formulations. The formulation used in this study was the same used in a previous study that analyzed the erosive potential of candies ${ }^{11}$. In this study, candies diluted in water had $\mathrm{pH}$ values below 5.5 , corroborating several studies ${ }^{11-16}$. This $\mathrm{pH}$ value refers to the critical value for dissolution of hydroxyapatite used as a reference for determining the erosive potential of these products $^{3}$. The $\mathrm{pH}$ values increased upon dissolution in artificial saliva, reaching neutrality in non-fruit flavors, but remaining acid in fruit flavors. This $\mathrm{pH}$ rise after dilution in saliva was also found in a previous study ${ }^{11}$. This may be due to the dilution and buffering effect of saliva.

The chemical erosion of hard dental tissues occurs by the action of the hydrogen ion, $\mathrm{H}+$ and/or other anions that act as acid-derived chelating substances. The $\mathrm{H}+$ ion dissociates in water attacking the crystal surface, dissolving it by combining with carbonate or phosphate ions, which are components of the mineral structure of dental tissues, causing the demineralization of dental tissues ${ }^{17}$. In all analyzed products in this study, ascorbic and citric acids were present in their composition, according to the manufacturer. But observing the changes in $\mathrm{pH}$ and titratable acidity, it suggests that there are variations in their concentrations among the different flavors.

Citric acid has a more complex interaction with the tooth structure. In an aqueous solution, it is a mixture of $\mathrm{H}+$ ions, acid anions (citrate) and non-dissociated acid molecules. The amounts of each component vary depending on $\mathrm{pH}$ and the acid dissociation constant ${ }^{17}$. The capacity of citrate to link with complex calcium ions, removes the crystal surface and/or saliva, and so increases the erosive wear ${ }^{17}$.

In addition to $\mathrm{pH}$, titratable acidity also strongly influences the erosive potential of a product ${ }^{18}$. Analyzing the titratable acidity, it was observed that only fruit candies in both groups showed significant acidity. It was also demonstrated that after dissolution in artificial saliva, fruit flavors reduced acidity significantly. This reduction was also observed in a previous study with single-flavor ${ }^{11}$ candies. A recent study demonstrated that the titratable acidity of a beverage influences more the salivary $\mathrm{pH}$ after consumption of an acidic beverage than the $\mathrm{pH}$ of the beverage ${ }^{19}$.

The literature suggests that during consumption of acid candies, there is a drop in $\mathrm{pH}$ and increased salivary flow. Only after consumption, with times ranging from 2 to $5 \mathrm{~min}$, salivary $\mathrm{pH}$ returns to neutral ${ }^{14,20,21}$

Studies on the consumption of hard candies, as analyzed in the present study, have shown that the average consumption time may reach $15 \mathrm{~min}^{14}$, a period in which there is change in salivary $\mathrm{pH}$. Thus, the frequent consumption of acidic hard candies may contribute to the development of dental erosion, as they are slowly dissolved by saliva in the oral cavity ${ }^{20,21}$. Thus, while saliva plays a protective role, its effect is partial ${ }^{11,21}$. Whereas the normal salivary flow of stimulated saliva ranges from 1 to $3 \mathrm{~mL} / \mathrm{min}$, in low flow from 0.7 to $1.0 \mathrm{~mL} / \mathrm{min}$ and under hypo salivation conditions, it may reach values below $0.7 \mathrm{~mL} /$ $\min ^{22}$ The salivary protection undergoes significant variations among individuals. This is especially important in patients with compromised protective saliva capacity due to the presence of diseases and use of drugs that affect the salivary flow. In these patients, even products with low erosivity may represent a risk to dental erosion. In this research was used a ratio of $1 \mathrm{~g}$ of candy powder to $6 \mathrm{~mL}$ of artificial saliva, which would amount to a condition of salivary flow of 2-6 min (3 mL-1) for each gram of candy powder.

The formulation of the artificial saliva of this study contains phosphate and bicarbonate buffer, as in natural saliva. The concentration of these compounds in natural saliva presents variations both among individuals and in stimulated and nonstimulated salivation. In stimulated salivation, the phosphate system has low concentration, but in non-stimulated saliva, it can reach peaks of $10 \mathrm{mM}$, showing its maximum buffer capacity in $\mathrm{pH}$ range of 6.8-7.2. The concentration of bicarbonate ions ranges from less than $1 \mathrm{mM}$ in non-stimulated saliva to $60 \mathrm{mM}$ in high flow rates ${ }^{22}$.

In view of the above, the complexity of the salivary dynamics cannot be fully described by in vitro studies, which is a limitation of this study. In addition, the erosive acid products comprise the interaction among physical, chemical and biological and behavioral factors ${ }^{2}$. Thus, it may be inferred that the analyzed candies have erosive potential, but their erosivity must be investigated by in situ and in vivo studies that include all the dynamics of the oral environment and quantify the mineral loss on exposure to potentially erosive agents. According to the present results, all the evaluated candies are acid and fruit flavors presented the lowest $\mathrm{pH}$ values. Dilution in artificial saliva raised their $\mathrm{pH}$ and lowered their titratable acidity, reducing their erosive potential.

Aiming to prevent and control dental erosion, the most significant strategy against extrinsic factors is the reduction or elimination of the erosive agent. In the case of candies, one should avoid their daily consumption and for extended periods. Additional measures, such as chewing sugar-free candies, rinsing teeth with water after candy consumption and using fluoridated toothpaste are also recommended ${ }^{6}$.

\section{Acknowledgements}

To the Scientific Initiation Program PROBIC/ ice-Dean of Research, Graduate Program, Extension and Culture at the 
University of Vale do Itajaí - UNIVALI, which funded the research.

\section{References}

1. Lussi A, Schlueter N, Rakhmatullina E, Ganss C. Dental erosion-An overview with emphasis on chemical and hispopatholigicol aspects. Caries Res. 2011;45 Suppl 1:2-12. doi: 10.1159/000325915.

2. Magalhães AC, Rios D, Honorio HM, Buzalaf MAR. Insights into preventive measures for dental erosion. J Appl Oral Sci. 2009 MarApr;17(2):75-86.

3. West NX, Joiner A. Enamel mineral loss. J Dent. 2014 Jun;42 Suppl 1:S2-11. doi: 10.1016/S0300-5712(14)50002-4.

4. Furtado JR, Freire VC, Messias DCF, Turssi CP. [Physicolchemical aspects related to the erosive potential of acid beverages]. RFO UPF. 2010;15(3): 325-30. Portuguese.

5. Gambon DL, Brand HS, Veerman ECI, Dental erosion in the 21st century: What is happening to nutritional habits and lifestyle in our society? Br Dent J. 2012 Jul 27;213(2):55-7. doi: 10.1038/ sj.bdj.2012.613.

6. Feltham EB. The power of sour candies: A dental hygienist's battle against dietary dental erosion. CDHA J. 2010;25(1):16-8.

7. Correa MSNP, Corrêa FNP, Correa JPNP, Murakami C, Mendes FM. Prevalence and associated factors of dental erosion in children and adolescents of a private dental practice. 2011 Nov;21(6):451-8. doi: 10.1111/j.1365-263X.2011.01150.x.

8. Sovik JB, Skudutyte-Rysstad R, Tveit A B, Sandvik L, Mulic A. Sour sweets and acidic beverage consumption are risk indicators for dental erosion. 2015;49(3):243-50. doi: 10.1159/000371896.

9. Moynihan PJ. The role of diet and nutrition in the etiology and prevention of oral diseases. Bull World Health Organ. 2005 Sep;83(9):694-9.

10. Nadimi $H$, Wesamaa H, Janket SJ, Bollu P, Meurman JH. Are sugar- free confections really beneficial for dental health? Br Dent J. 2011 Oct 7;211(7):E15. doi: 10.1038/sj.bdj.2011.823.

11. Wagoner SN, Marshall TA, Quian F, Wefel JS. In vitro enamel erosion associated with commercially available original and sour candies. J Am Dent Assoc. 2009 Jul;140(7):906-13.

12. Davies R, Hunter L, Loyn T, Rees J. Sour sweets: a new type of erosive challenge? Br Dent J. 2008 Jan 26;204(2):E3; discussion 84-5.

13. Brand HS, Gambon DL, Paap A, Bulthuis MS, Veerman EC, Amerongen AV. The erosive potential of lollipops. Int Dent J. 2009 Dec;59(6):358-62.

14. Brand Hs, Gambon DL, Van Dop LF, Van Liere LE, Veerman EC. The erosive potential of jawbreakers. Int J Dent Hyg. 2010 Nov;8(4):308-12. doi: 10.1111/j.1601-5037.2010.00450.x

15. Silva JG, Farias MMAG, Silveira EG, Araújo SM, Schmitt BHE Evaluation of the erosive potential of acidic candies consumed by children and teenagers. J Pharm Nutr Sci. 2013;3(4):262-5.

16. Lazzaris M, Farias MMAG, Araújo SM, Schmitt BEH, Silveira EG Erosive potential of commercially available candies. Braz Res Pediatr Dent Integr Clin. 2015;15(1):7-12. doi: 0.4034/PBOCI.2015.151.01.

17. Featherstone JDB, Lussi $A$. Understanding the chemistry of dental erosion. Monogr Oral Sci. 2006;20:66-76.

18. Lussi A, Jaeggi T. Chemical factors. Monogr Oral Sci. 2006;20:77-87.

19. Tenuta LMA, Fernández CE, Brandão ACS, Cury JA. Titratable acidity of beverages influences salivary pH recovery. Braz Oral Res. 2015;29. pii: S1806-83242015000100234. doi: 10.1590/1807-3107BOR-2015. vol29.0032

20. Gambon DL, Brand HS, Amerongen AVN. [Acidic candies affect saliva secretion rates and oral fluid acidity]. Ned Tijdschr Tandheelkd 2007 Aug;114(8): 330-4. Dutch.

21. Jensdottir T, Nauntofte B, Buchwald C, Bardow A. Effects of sucking acidic candy on whole mouth saliva composition. Caries Res 2005 Nov-Dec;39(6):468-74

22. Tenevuo J, Lagerloj F. [Saliva]. In: Thylstrup A, Fejerskov O. [Clinical cariology]. São Paulo: Santos; 1995. p.17-43. Portuguese. 